\begin{tabular}{|c|c|c|}
\hline$\Leftrightarrow$ & $\begin{array}{l}\text { Al Fitrah } \\
\text { Journal Of Early Childhood Islamic Education } \\
\text { ISSN : 2599-2287 } \\
\text { Vol.1 No.2 Januari } 2018\end{array}$ & $\begin{array}{r}\text { Pengajaran Konsep Matematika Pada Anak } \\
\text { Usia Dini } \\
\text { Fatrima Santri Syafri }\end{array}$ \\
\hline
\end{tabular}

\title{
PENGAJARAN KONSEP MATEMATIKA PADA ANAK USIA DINI
}

\begin{abstract}
Abstrak
Pada Usia dini (prasekolah) adalah usia yang efektif dalam mengembangkan berbagai potensi yang dimiliki anak. Masa ini disebut masa keemasan (golden ages) sebab masa anak yang sangat peka untuk menerima rangsanganrangsangan dari lingkungannya, baik yang berkaitan dengan aspek moral agama, sosial emosional, bahasa, kognitif dan fisik. Matematika prasekolah tidak terletak pada penguasaan aritmatika dasar. Namun, memberikan pengalaman matematika dalam permainan mereka, menjelaskan, dan berpikir tentang dunia mereka. Pengalaman matematika tersebut lebih mengenalkan siswa pada konsep matematika. Konsep matematika adalah ide abstrak dalam menggolongkan matematika berdasarkan karakteristik tertentu atau menggolongkan contoh dan bukan contoh dalam matematika. Konsep dasar yang dapat dikenalkan pada siswa PAUD yaitu konsep berhitung dan konsep geometri. Kedua konsep tersebut dalam pengajarannya, siswa PAUD dikenalkan dengan beberapa benda yang berada dilungkungan sekitar mereka sehingga konsep matematika tersebut dapat dipahami dan dimengerti lebih mendalam oleh para siswa. Misalnya dalam berhitung, siswa dikenalkan dengan jumlah benda yang ada disekitar mereka, seperti permen, kelereng dan lainnya. Untuk benda geometri misalnya dikenalkan bentuk bola, lingkaran dan lainnya dengan benda-benda yang menyerupai bentuk geometri tersebut.
\end{abstract}

Kata Kunci : Pengajaran, Konsep Matematika, AUD

\section{Pendahuluan}

Seorang Anak adalah anugerah dari Allah SWT yang memiliki potensi yang dapat dikembangkan. Anak juga mempunyai karakteristik tertentu yang tidak sama dengan

\section{Fatrima Santri Syafri}

Email : kimarakim21@gmail.com fatrimasantrisyafri@iainbengkulu.ac.id IAIN Bengkulu 


\begin{tabular}{|c|c|c|}
\hline 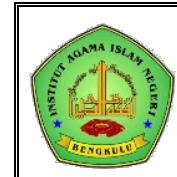 & $\begin{array}{l}\text { A1 Fitrah } \\
\text { Journal Of Early Childhood Islamic Education } \\
\text { ISSN : 2599-2287 } \\
\text { Vol.1 No.2 Januari } 2018\end{array}$ & $\begin{array}{r}\text { Pengajaran Konsep Matematika Pada Anak } \\
\text { Usia Dini } \\
\text { Fatrima Santri Syafri }\end{array}$ \\
\hline
\end{tabular}

Pada Usia dini (prasekolah) adalah usia yang efektif dalam mengembangkan berbagai potensi yang dimiliki anak. Masa ini disebut masa keemasan (golden ages) sebab masa anak yang sangat peka untuk menerima rangsangan-rangsangan dari lingkungannya, baik yang berkaitan dengan aspek moral agama, sosial emosional, bahasa, kognitif dan fisik. Potensi yang dimiliki dapat dirangsang dan dikembangkan agar anak dapat berkembang secara optimal. Maka dibutuhkan kondisi atau tempat pendidikan yang sesuai dengan kebutuhan dan perkembangan anak dan agar tujuan pendidikan tercapai secara optimal ${ }^{1}$.

Anak prasekolah yang mengikuti PAUD berdasarkan pendapat Solehuddin ${ }^{2}$ memiliki fungsi utama, yaitu (1) fungsi pengembangan potensi, (2) fungsi penanaman dasar-dasar aqidah dan keimanan, (3) fungsi pembentukan dan pembiasaan perilakuperilaku yang diharapkan, (4) fungsi pengembangan pengetahuan dan keterampilan dasar yang diperlukan, dan (5) fungsi pengembangan motivasi dan sikap belajar yang positif. Apabila dikaitkan dengan kemampuan matematika maka merujuk dari Permendikbud Nomor 137

\footnotetext{
${ }^{1}$ Sujiono, Yuliani Nurani, 2009. Konsep Dasar Pendidikan Anak Usia Dini, Jakarta: PT Indeks. HIm. 56

${ }^{2}$ Solehuddin, Konsep Dasar Pendidikan Prasekolah, ( IKIP Bandung: Tidak Diterbitkan, 1997), h.50
}

Tahun 2014 aspek kognitif merupakan salah satu aspek perkembangan dalam PAUD. Aspek kognitif tersebut diantaranya adalah

a. Belajar dan pemecahan masalah, mencakup kemampuan memecahkan masalah sederhana dalam kehidupan sehari-hari dengan cara fleksibel dan diterima sosial serta menerapkan pengetahuan atau pengalaman dalam konteks yang baru;

b. Berfikir logis, mencakup berbagai perbedaan, klasifikasi, pola, berinisiatif, berencana, dan mengenal sebab-akibat; dan

c. Berfikir simbolik, mencakup kemampuan mengenal, menyebutkan, dan menggunakan konsep bilangan, mengenal huruf, serta mampu merepresentasikan berbagai benda dan imajinasinya dalam bentuk gambar.

Pada Anak usia prasekolah menurut Clements $^{3}$ merupakan waktu yang tepat untuk memberikan ketertarikan untuk berhitung, menyusun, membentuk bangunan, menemukan pola, mengukur, dan memperkirakan. Matematika prasekolah tidak terletak pada penguasaan aritmatika dasar. Namun, memberikan pengalaman

\footnotetext{
${ }^{3}$ Clements, D., Mathematics in the Preschool, (Teaching Children Mathematics: NCTM, 2001), hlm. 270.
} 


\begin{tabular}{|c|c|c|}
\hline$+i^{*}$ & $\begin{array}{l}\text { Al Fitrah } \\
\text { Journal Of Early Childhood Islamic Education } \\
\text { ISSN : 2599-2287 } \\
\text { Vol.1 No.2 Januari } 2018\end{array}$ & $\begin{array}{r}\text { Pengajaran Konsep Matematika Pada Anak } \\
\text { Usia Dini } \\
\text { Fatrima Santri Syafri }\end{array}$ \\
\hline
\end{tabular}

matematika dalam permaianan mereka, segitiga dan rumus luas bangun datar yang menjelaskan, dan berpikir tentang dunia lain ${ }^{5}$.

mereka.

Menurut Soedjadji mengatakan

Berdasarkan beberapa pemahaman di bahwa konsep-konsep dalam matematika atas, maka perlu adanya perhatian khusus pada umumnya disusun dari konsep-konsep dalam pengajaran matematika untuk anak sebelumnya. Misalnya konsep pangkat usia dini (PAUD). Pengajaran matematika disusun dari konsep perkalian, konsep luas dalam hal penyampaian konsep matematika, segitiga disusun dari konsep luas persegi harus disesuaikan dengan perkembangan dari panjang, konsep luas trapesium disusun dari anak usia dini tersebut.

\section{Pembahasan}

\section{Konsep Matematika}

Menurut Farrel dan Farmer konsep luas segitiga. Berarti konsep-konsep sebelumnya yang dipahami siswa sangat dibutuhkan untuk mengkonstruksi suatu konsep baru ${ }^{6}$.

Berdasarkan beberapa pendapat di mendefinisikan konsep sebagai suatu klasifikasi dari objek-objek, sifat-sifat objek atau kejadian-kejadian yang ditentukan dengan cara mengabstrasikannya ${ }^{4}$. Selanjutnya berdasarkan Gagne mengemukakan bahwa konsep dalam matematika adalah ide abstrak yang meyakinkan orang dapat mengklasifikasikan objek-objek atau kejadian-kejadian kedalam contoh atau bukan contoh dari suatu objek tertentu. Misalnya seorang siswa telah memahami konsep luas segitiga, maka siswa tersebut akan dapat membedakan rumus luas

\footnotetext{
${ }^{4}$ Musliana. 2007. Pengaruh Penggunaan Model Pembelajaran Konstrutivis Terhadap Prestasi Belajar Matematika Siswa Kelas IV SDN 11 Abeli. Skripsi. Kendari: FKIP Universitas Haluoleo. hlm.7
} atas, maka konsep matematika adalah ide abstrak dalam menggolongkan matematika berdasarkan karakteristik tertentu atau menggolongkan contoh dan bukan contoh dalam matematika.

Dienes mengemukakan agar pemahaman akan konsep-konsep matematika mampu dipahami oleh siswa lebih mendasar harus maka perlu diadakan pendekatan belajar dalam mengajarkan konsep antara lain (a) siswa yang belajar matematika harus menggunakan benda-benda konkret dan

\footnotetext{
5 Arsat. 2007. Meningkatkan Pemahaman Konsep Luas Bangun Datar Melalui Representasi Enaktif, Ikonik dan Simbolik pada Siswa kelas SDN 8 Baruga Kendari. Skripsi. Kendari: FKIP Universitas Haluoleo Kendari. hlm.8

${ }^{6}$ Soedjadji, R. 2000. Kiat Pendidikan Matematika Di Indonesia. Jakarta: Dirjen DIKTI. hlm.11
} 


\begin{tabular}{|c|c|c|}
\hline 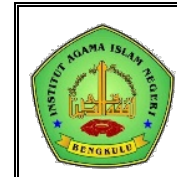 & $\begin{array}{l}\text { A1 Fitrah } \\
\text { Journal Of Early Childhood Islamic Education } \\
\text { ISSN : 2599-2287 } \\
\text { Vol.1 No.2 Januari } 2018\end{array}$ & $\begin{array}{r}\text { Pengajaran Konsep Matematika Pada Anak } \\
\text { Usia Dini } \\
\text { Fatrima Santri Syafri }\end{array}$ \\
\hline
\end{tabular}

membuat abstraksinya dari konseppekerjaan dini anak-anak dengan konsepnya; (b) materi pelajaran yang akan bilangan.

diajarkan harus ada hubungannya atau pengaitan yang sudah dipelajari; (c) supaya siswa memperoleh sesuatu dari belajar matematika harus mengubah suasana abstrak dengan menggunakan simbol-simbol. ${ }^{7}$

\section{Matematika Pada Anak Usia Dini}

National Council of Teacher Of Mathematics (NCTM) telah mengembangkan The principles and strandards for school mathematics (prinsip dan standar untuk matematika sekolah) memaparkan harapan matematika pada anak usia dini tentang konsep-konsep yang bisa dipahami anak usia dini dalam matematika antara lain ${ }^{8}$ :

1. Bilangan

Salah satu konsep matematika yang paling penting dipelajari anak adalah pengembangan kepekaan bilangan. Peka terhadap bilangan berarti tidak sekedar menghitung. Kepekaan bilangan itu mencakup pengembangan rasa kuantitas dan pemahaman kesesuaian satu lawan satu. Ketika kepekaan terhadap bilangan anak-anak berkembang, mereka menjadi semakin tertarik pada hitung-menghitung. Menghitung ini menjadi landasan bagi

\footnotetext{
${ }^{7}$ Arsat. loc.cit

${ }^{8}$ NCTM.Principles and Standars for School Mathematics. Reston, VA: NCTM. 2000. HIm. 67
}

2. Aljabar

Pengenalan aljabar dimulai dengan menyortir, menggolongkan, membandingkan, dan menyusun bendabenda menurut bentuk, jumlah, dan sifatsifat lain, mengenal, menggambarkan, dan memperluas pola akan memberi sumbangan kepada pemahaman anak-anak tentang penggolongan.

3. Penggolongan

Penggolongan (klasifikasi) adalah salah satu proses yang penting untuk mengembangakn konsep bilangan. Supaya anak mampu menggolongkan atau menyortir benda-banda, mereka harus mengembangkan pengertian tentang “saling memiliki kesamaan”, “keserupaan”, “kesamaan”, dan “perbedaan”.

4. Pola-pola

Mengidentifikasi dan menciptakan pola dihubungkan dengan penggolongan dan penyortiran. Anak mulai melihat atribut-atribut yag sama dan berbeda pada gambar dan benda-benda. Anak-anak senang membuat pola di lingkungan mereka.

\section{Geometri}




\begin{tabular}{|c|c|c|}
\hline & $\begin{array}{l}\text { Al Fitrah } \\
\text { Journal Of Early Childhood Islamic Education } \\
\text { ISSN : 2599-2287 } \\
\text { Vol.1 No.2 Januari } 2018\end{array}$ & $\begin{array}{r}\text { Pengajaran Konsep Matematika Pada Anak } \\
\text { Usia Dini } \\
\text { Fatrima Santri Syafri }\end{array}$ \\
\hline
\end{tabular}

Membangun konsep geometri pada anak di mulai dengan mengidentifikasi bentuk-bentuk, menyelidiki bangunan dan memisahkan gambar-gambar biasa seperti segi empat, lingkaran, segitiga. Belajar konsep letak seperti dibawah, di atas, kiri, kanan meletakkan dasar awal memahami geometri.

\section{Pengukuran}

Ketika anak mempunyai kesempatan untuk pengalaman-pengalaman langsung untuk mengukur, menimbang, dan membandingkan ukuran benda-benda, mereka belajar konsep pengukuran. Melalui pengalaman ini anak mengembangkan sebuah dasar kuat dalam konsep-konsep pengukuran.

7. Analisis data dan probabilitas

Percobaan dengan pengukuran, penggolongan, dan penyortiran merupakan dasar untuk memahami probabilitas dan analisis data. Ini berarti mengemukakan pertanyaan, mengumpulkan informasi tentang dirinya dan lingkungan mereka, dan menyampaikan informasi ini secara hidup.

Dienes merumuskan 6 tahap berpikir matematika ${ }^{9}$. Pertama adalah free play, anak diberi kebebasan untuk berinteraksi dengan

${ }^{9}$ Brousseau, Theory of Didactical Situations in Mathematics, (Netherlands: Kluwer Academic Publisher, 1997), h.139-142 lingkungan. Kebebasan dalam arti, kegiatan pembelajaran tahap awal dilakukan dengan memberi keleluasaan pada siswa mengenal, memperhatikan, mengidentifikasi segala bentuk permainan atau benda-benda konkrit yang disediakan dalam pembelajaran. Kedua games, pada tahap ini diberikan aturan sebelum dimulai dan beberapa kriteria yang harus dicapai sehingga dapat dikategorikan tujuan permainan tersebut tercapai.

Generalisasi sebagai tahap ketiga anak mengenal pola, kesamaan, dan sifat umum pada model yang berbeda ${ }^{10}$. Tahap keempat, representasi, anak diberikan kebebasan untuk mengekspresikan suatu metode atau cara untuk mewakili semua aktivitas games yang memiliki kesamaan struktur. Kebebasan berekspresi siswa dapat diwujudkan dalam bentuk visual maupun audio. Bentuk representasi visual misalkan adalah: gambar, bilangan atau angka, grafik. Tahap kelima simbolisasi, terjadi ketika anak menggunakan formula dan kata-kata untuk mendeskripsikan hubungan. Misalkan representasi simbol luas dan keliling. Terakhir tahap formalisasi, hubungan dan sifat gambar yang dikelompokkan, diurutkan, dan dikenal sebagai bagian dari struktur konsep matematika. Anak pada tahap awal

\footnotetext{
${ }^{10}$ Novikasari, ifada (2016) Matematika dalam Program Pendidikan Anak Usia Dini (PAUD). Bunayya: Jurnal Pendidikan Anak, Vol 2 (1), hlm 7
} 


\begin{tabular}{|c|c|c|}
\hline 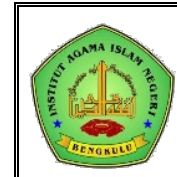 & $\begin{array}{l}\text { A1 Fitrah } \\
\text { Journal Of Early Childhood Islamic Education } \\
\text { ISSN : 2599-2287 } \\
\text { Vol.1 No.2 Januari } 2018\end{array}$ & $\begin{array}{r}\text { Pengajaran Konsep Matematika Pada Anak } \\
\text { Usia Dini } \\
\text { Fatrima Santri Syafri }\end{array}$ \\
\hline
\end{tabular}

belajar atau prasekolah sampai pada tahap simbolisasi untuk memaknai dunia dengan matematika.

\section{Pengajaran Konsep Matematika Pada}

\section{Anak Usia Dini}

Pelaksanaan pembelajaran sekarang ini banyak menginspirasi dari empat ahli psikologi kognitif terkenal diantaranya adalah Piaget, Vygotsky, Bruner,dan Dienes. Gagasan atau ide mereka didasarkan pada teori konstruktivisme. Pada teori tersebut memandang anak dapat berkreasi dengan pengetahuannya yang bersumber dari aktivitas mental sehingga menghasilkan pengalamana dari dunia sekitarnya dan menemukan makna dari kegiatan tersebut. ${ }^{11}$

Berdasarkan keempat ahli psikologi kognitif (Piaget, Vygotsky, Bruner,dan Dienes ) memberikan beberapa petunjuk yang sama mengenai proses anak untuk mengenal matematika dalam PAUD. Pada Anak usia 3 sampai dengan 6 tahun dapat mengenal matematika melalui benda-benda di lingkungan mereka dan untuk tingkat sedikit di atasnya melalui benda manipulatif. Selanjutnya anak mampu memberikan representasi atas benda-benda tersebut. Misalkan guru menyediakan beberapa bungkus permen dan pada akhir proses

11 Sperry, S.S., Early Childhood Mathematics: Third Edition, (Boston: Pearson, 2006), hlm. 14-16. bermain anak sudah mampu memberikan representasi 'satu bungkus permen'...'dua bungkus permen'..dan seterusnya ${ }^{12}$.

Matematika merupakan alat untuk membantu anak memahami dan menganalisa dunianya. Cara matematika adalah dengan deskripsi dan representasi kuantitas, bentuk, ruang, dan pola yang membantu pengorganisasian pengetahuan dan ide dengan cara yang sistematis. Sistem matematika tersebut menjadi bagian penting dalam kehidupan masyarakat. Standar dalam matematika di PAUD yang perlu diberikan sebagai penduan pengembangan pengalaman matematika yang sesuai bagi anak. Beberapa pengembangan pengalaman berarti dapat memberikan tantangan sesuai dengan usia anak, fleksibel dalam variasi respon anak, dan sesuai dengan cara berpikir dan belajar anak ${ }^{13}$.

Matematika di PAUD memuat dua bidang inti, yaitu (1) bilangan dan (2) geometri dan pengukuran. Kedua bidang tersebut penting sebagai persiapan sekolah dan penting dalam kehidupan sehari-hari ${ }^{14}$.

Beberapa penerapan aplikasi pengajaran yang dapat diberikan guru dalam mengajar matematika yaitu dengan

\footnotetext{
${ }^{12}$ Novikasari. op.cit. hlm 7-8

13 National Research Council, Mathematics Learning in Early Childhood: Paths Toward Excellence and Equity (Washington: The National Academies Press, 2009), h.21

${ }^{14}$ Novikasari. op.cit. hlm 8
} 


\begin{tabular}{|l|l|r|}
\hline \begin{tabular}{|l|l|} 
Al Fitrah \\
Journal Of Early Childhood Islamic Education \\
ISSN : 2599-2287
\end{tabular} & $\begin{array}{r}\text { Pengajaran Konsep Matematika Pada Anak } \\
\text { Usia Dini } \\
\text { Vol.1 No.2 Januari 2018 }\end{array}$ \\
\hline
\end{tabular}

memberikan materi-materi yang langsung PAUD. Seperti yang ditampilkan berikut ini : berhubungan dengan kehidupan anak-anak

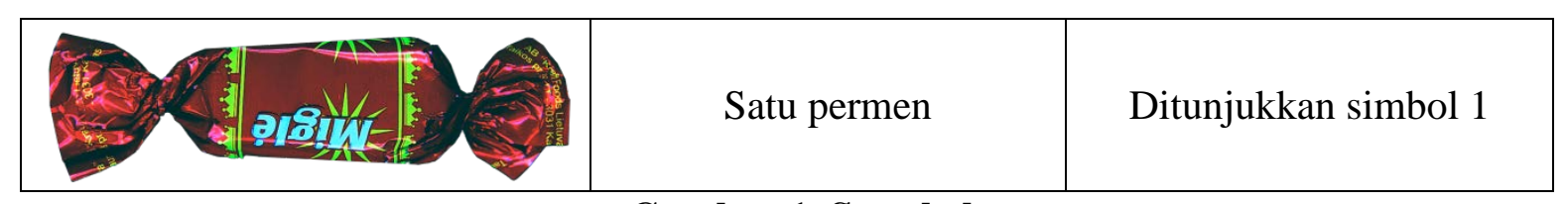

\section{Gambar 1. Satu kelereng}

Dari gambar di atas, siswa diberikan menunjukkan bahwa simbol satu adalah 1 . satu bungkus permen, yang menyatakan Sehingga para siswa mengetahui bahwa satu bahwa ada satu bungkus permen dimana guru dapat ditulis dengan angka 1.

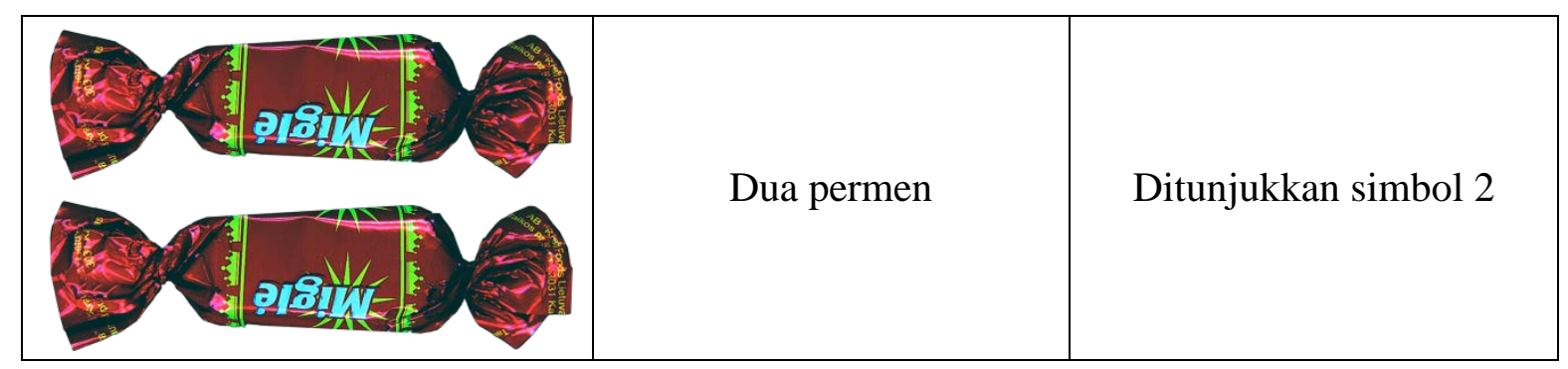

Gambar 2. Satu kelereng

Dari gambar di atas, siswa diberikan menunjukkan bahwa simbol dua adalah 2. dua bungkus permen, yang menyatakan Sehingga para siswa mengetahui bahwa dua bahwa ada dua bungkus permen dimana guru dapat ditulis dengan angka 2.

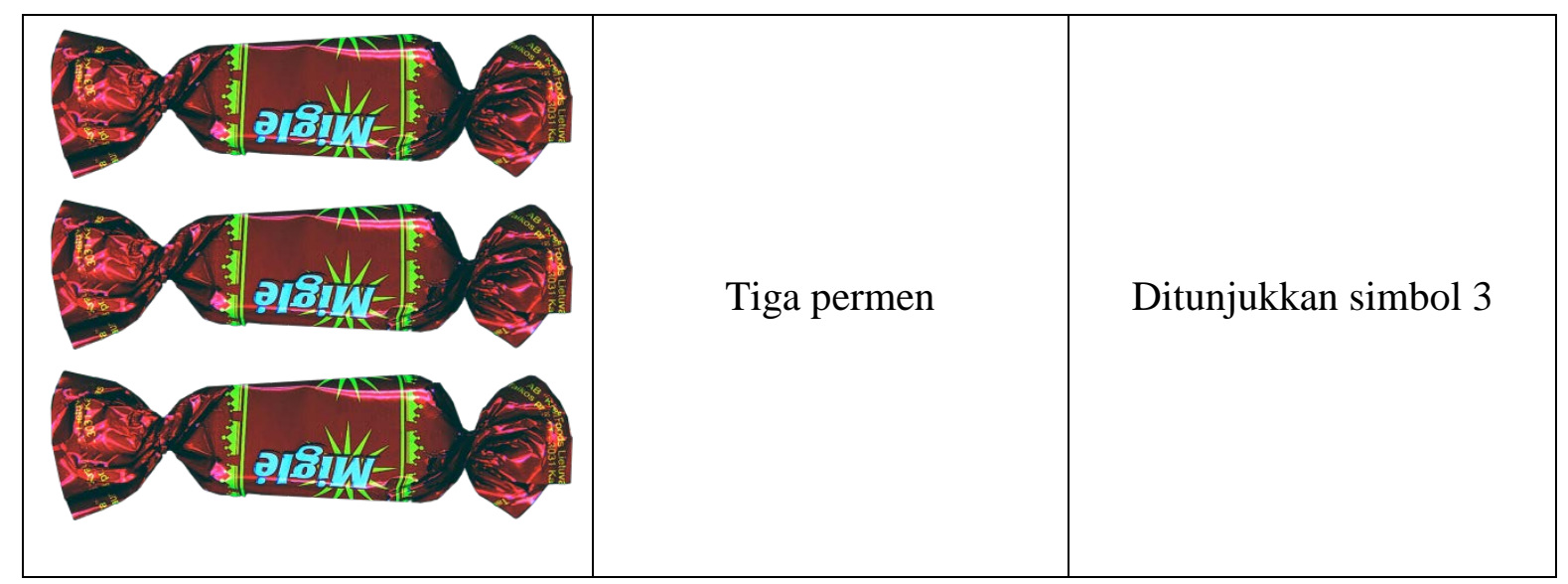

Gambar 3. Satu kelereng

Dari gambar di atas, siswa diberikan menunjukkan bahwa simbol tiga adalah 3. dua bungkus permen, yang menyatakan Sehingga para siswa mengetahui bahwa tiga bahwa ada tiga bungkus permen dimana guru dapat ditulis dengan angka 3. 


\begin{tabular}{|c|c|c|}
\hline 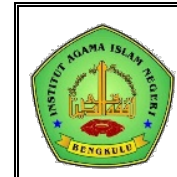 & $\begin{array}{l}\text { A1 Fitrah } \\
\text { Journal Of Early Childhood Islamic Education } \\
\text { ISSN : 2599-2287 } \\
\text { Vol.1 No.2 Januari } 2018\end{array}$ & $\begin{array}{r}\text { Pengajaran Konsep Matematika Pada Anak } \\
\text { Usia Dini } \\
\text { Fatrima Santri Syafri }\end{array}$ \\
\hline
\end{tabular}

Kegiatan ini dilakukan selanjutnya mengulang bahwa simbol angka tersebut hingga pada angka sepuluh ( 10 ). Pada hanya mewakili dari banyak benda. Dapat kegiatan ini guru tidak menekankan langsung dilakukan dengan menunjukkan banyaknya pada simbol, tetapi siswa diharapkan bahwa mainan siswa, misalnya kelereng, boneka, angka-angka tersebut hanyala mewakili dari karet gelang dan mainan lainnya.

banyaknya benda yang ditunjukkan tersebut. Untuk kegitan pembelajaran Kemudian untuk kegiatan pembelajaran berikutnya, yaitu tentang teknik / konsep berikutnya guru dapat mencoba dengan berhitung pada anak PAUD dapat dilakukan beberapa benda lainnya sehingga dapat sebagai berikut :

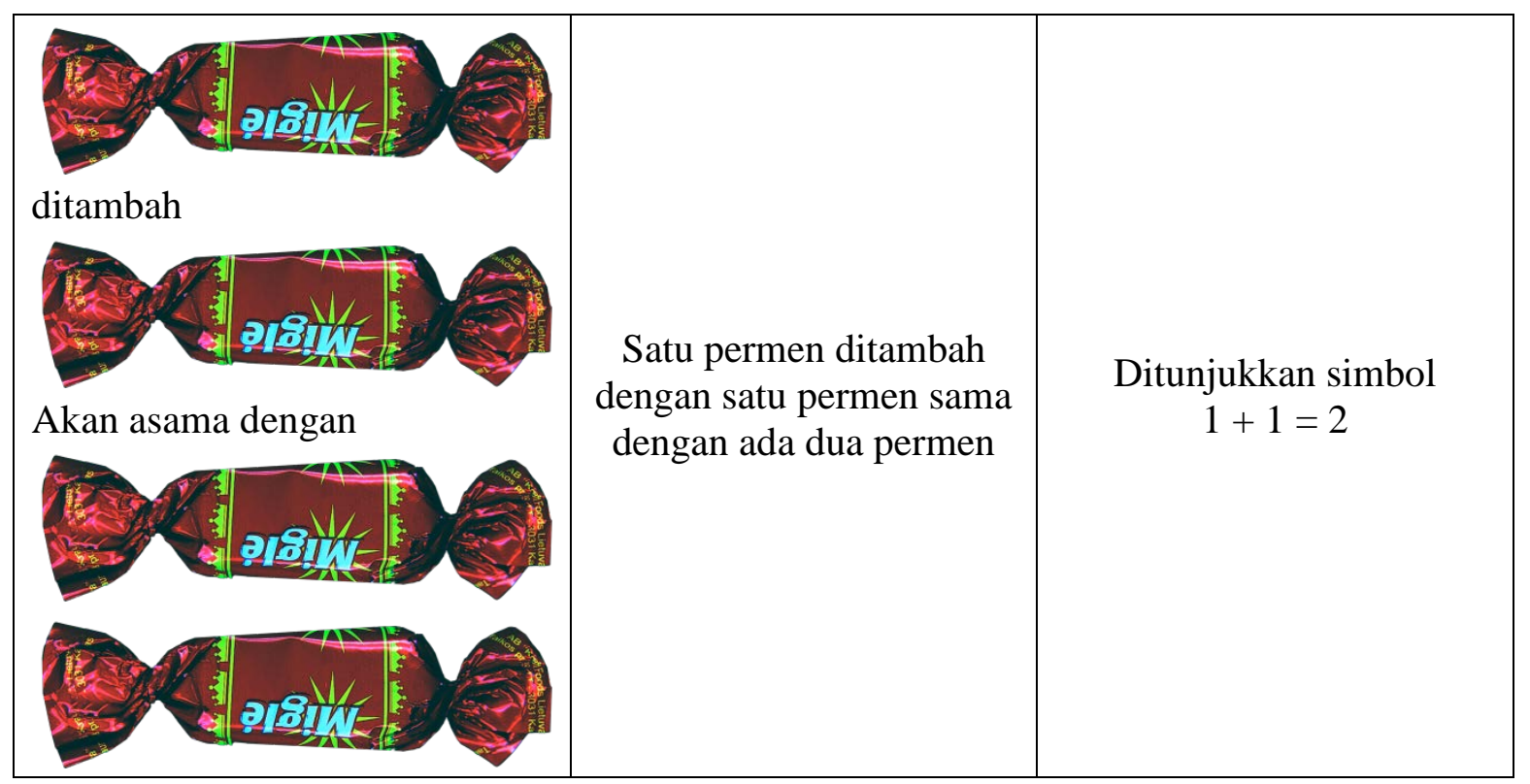

Gambar 4. Konsep Penjumlahan

Kegiatan ini, guru menunjukkan bahwa satu bungkus permen ditambah satu bungkus permen akan ada dua bungkus permen. Atau seorang guru dapat memisalkan seorang siswa diberikan satu bungkus permen kemudian selanjutnya diberikan kembali satu bungkus permen maka seorang anak tersebut akan memiliki dua permen. Misalnya guru dapat melakukan sebagai berikut :
"Ani mempunyai satu bungkus permen, kemudian Ani diberi Ibunya satu permen kembali, maka berapa permen yang Ani miliki sekarang?”

Dari kegiatan tersebut, guru mengiringi kegiatan tersebut dengan menuliskan simbol penjumlahan yang terbentuk dari permasalahn tersebut $1+1=2$. Sehingga siswa mampu mengerti bahwa simbol satu ditambah satu sama dengan dua tersebut. 


\begin{tabular}{|c|c|c|}
\hline$+i^{*}$ & $\begin{array}{l}\text { Al Fitrah } \\
\text { Journal Of Early Childhood Islamic Education } \\
\text { ISSN : 2599-2287 } \\
\text { Vol.1 No.2 Januari } 2018\end{array}$ & $\begin{array}{r}\text { Pengajaran Konsep Matematika Pada Anak } \\
\text { Usia Dini } \\
\text { Fatrima Santri Syafri }\end{array}$ \\
\hline
\end{tabular}

Kegiatan ini dapat dilakukan dengan seperti berikut:

memberikan contoh berikutnya, misalnya

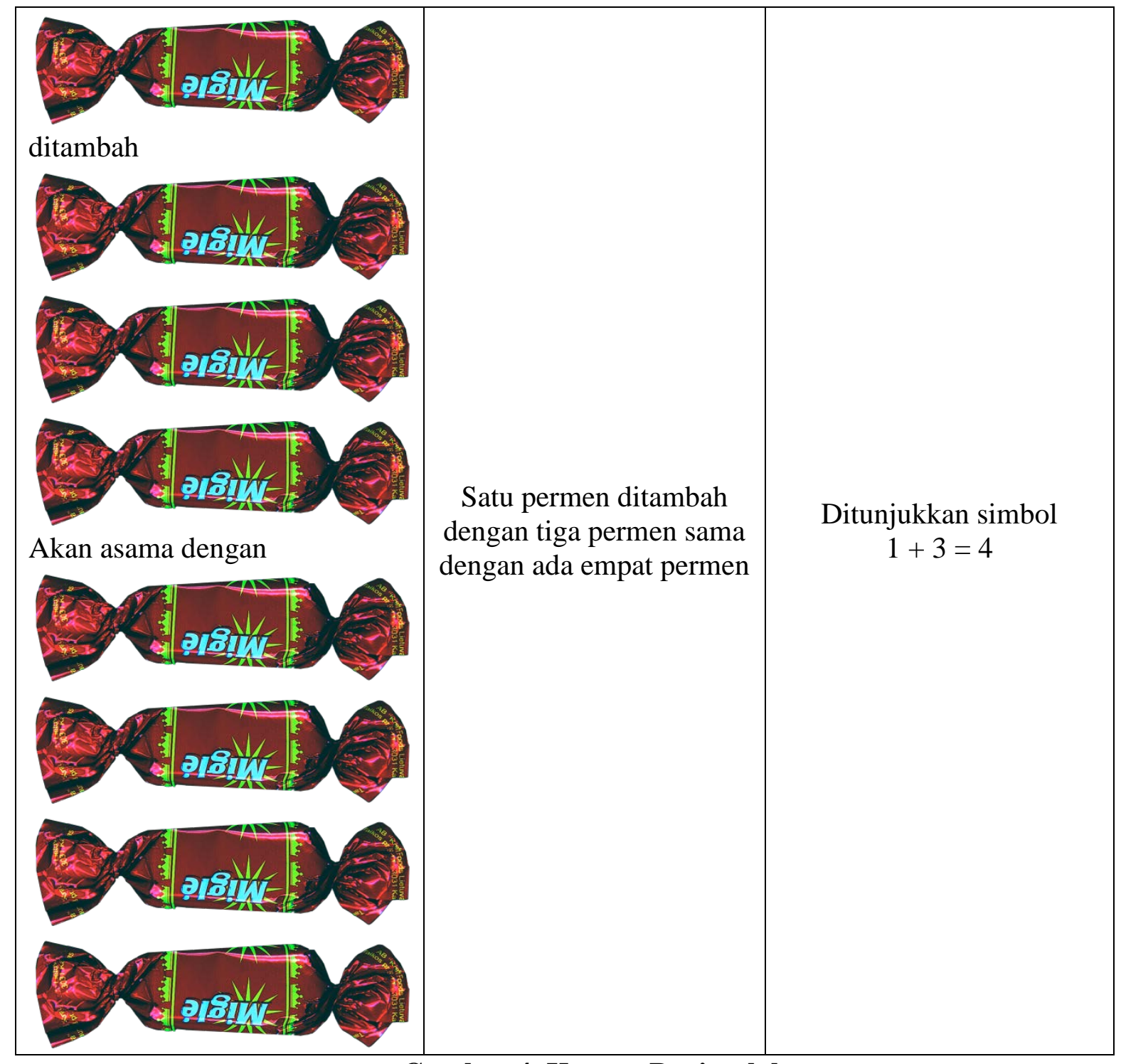

\section{Gambar 4. Konsep Penjumlahan}

Kegiatan ini, guru menunjukkan bahwa satu bungkus permen ditambah tiga bungkus permen akan ada empat bungkus permen. Atau seorang guru dapat memisalkan seorang siswa diberikan satu bungkus permen kemudian selanjutnya diberikan kembali tiga bungkus permen maka seorang anak tersebut akan memiliki empat bungkus permen.

Misalnya guru dapat melakukan sebagai berikut :

"Iwan mempunyai satu bungkus permen, kemudian Ani memberikan iwan tiga bungkus permen, maka berapa permen yang Iwan miliki sekarang?”

Dari kegiatan tersebut, guru mengiringi kegiatan tersebut dengan menuliskan simbol penjumlahan yang terbentuk dari 


\begin{tabular}{|c|c|c|}
\hline$\Leftrightarrow$ & $\begin{array}{l}\text { Al Fitrah } \\
\text { Journal Of Early Childhood Islamic Education } \\
\text { ISSN : 2599-2287 } \\
\text { Vol.1 No.2 Januari } 2018\end{array}$ & $\begin{array}{r}\text { Pengajaran Konsep Matematika Pada Anak } \\
\text { Usia Dini } \\
\text { Fatrima Santri Syafri }\end{array}$ \\
\hline
\end{tabular}

permasalahn tersebut $1+3=4$. Sehingga jenuh dengan hanya berfokus pada satu siswa mampu mengerti bahwa simbol satu benda. Misalnya dapat diganti dengan bendaditambah satu sama dengan dua tersebut. benda lainnya.

Kegiatan ini dapat dilakukan untuk menjelaskan konsep penjumlahan kepada siswa. Pembelajaran konsep penjumlahan ini dapat dilakukan dengan mencoba beberapa benda lainnya sehingga siswa tidak merasa berikut ini :

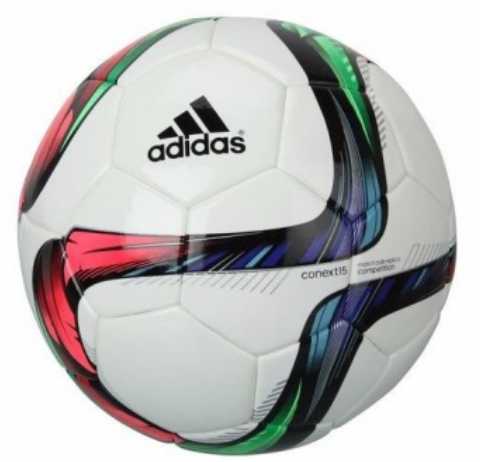

Gambar 5. Bola

Gambar bola dapat dikenalkan kepada lainnya yang dapat dikenalkan pada siswa siswa adalah bentuk bola yang dikenal dalam adalah, kelereng, bola pimpong, bola kasti geometri secara matematika. Bentuk bola dan bentuk berupa bola geometri lainnya.

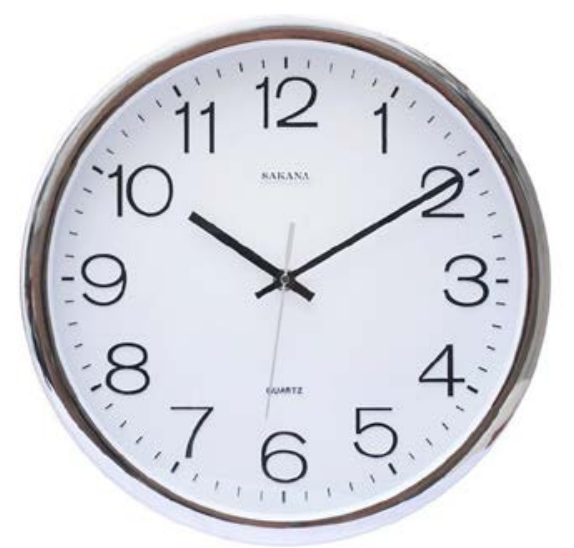

\section{Gambar 5. Bola}

Gambar jam dinding dapat dikenalkan kepada siswa adalah bentuk lingkaran yang dikenal dalam bentuk geometri secara matematika. Bentuk lingkaran lainnya yang dapat dikenalkan pada siswa adalah ban sepeda, dan bentuk berupa bola geometri lainnya. 


\begin{tabular}{|l|l|r|}
\hline \begin{tabular}{|l|} 
Al Fitrah \\
Journal Of Early Childhood Islamic Education \\
ISSN $:$ 2599-2287
\end{tabular} & $\begin{array}{r}\text { Pengajaran Konsep Matematika Pada Anak } \\
\text { Usia Dini } \\
\text { Vol.1 No.2 Januari 2018 }\end{array}$ \\
\hline
\end{tabular}

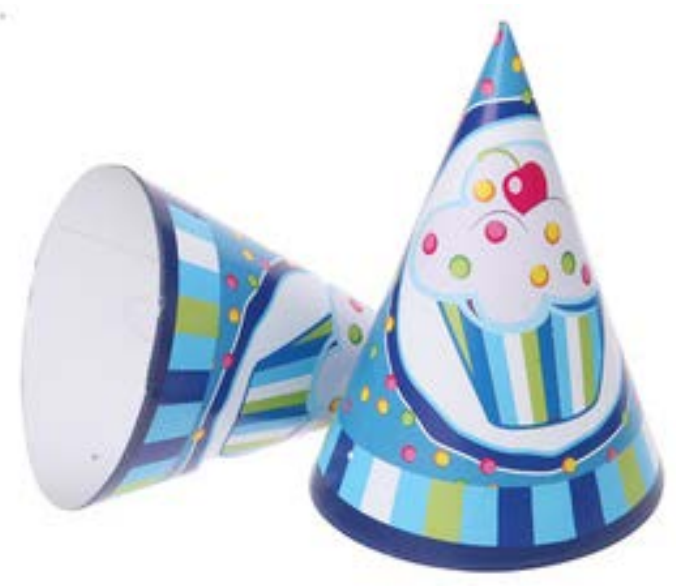

Gambar 6. Topi Kerucut

Guru dapat menjelaskan bentuk kerucut gambar 6 tersebut di atas. Seorang guru dapat dalam geometri dapat diwakili dengan memberikan contoh lainnya yang melihatkan bentuk topi kerucut seperti pada berhubungan dengan bentuk kerucut lainnya.

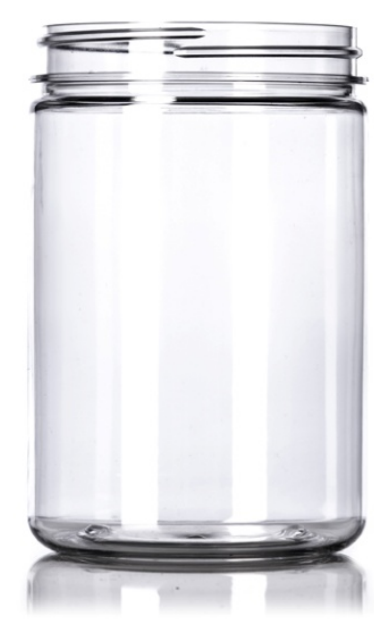

\section{Gambar 7. Toples}

Guru dapat menjelaskan bentuk tabung gambar 7 tersebut di atas. Seorang guru dapat dalam geometri dapat diwakili dengan memberikan contoh lainnya yang melihatkan bentuk toples seperti pada berhubungan dengan bentuk tabung lainnya. 


\begin{tabular}{|c|c|c|}
\hline$\Leftrightarrow$ & $\begin{array}{l}\text { Al Fitrah } \\
\text { Journal Of Early Childhood Islamic Education } \\
\text { ISSN : } 2599-2287 \\
\text { Vol.1 No.2 Januari } 2018\end{array}$ & $\begin{array}{r}\text { Pengajaran Konsep Matematika Pada Anak } \\
\text { Usia Dini } \\
\text { Fatrima Santri Syafri }\end{array}$ \\
\hline
\end{tabular}

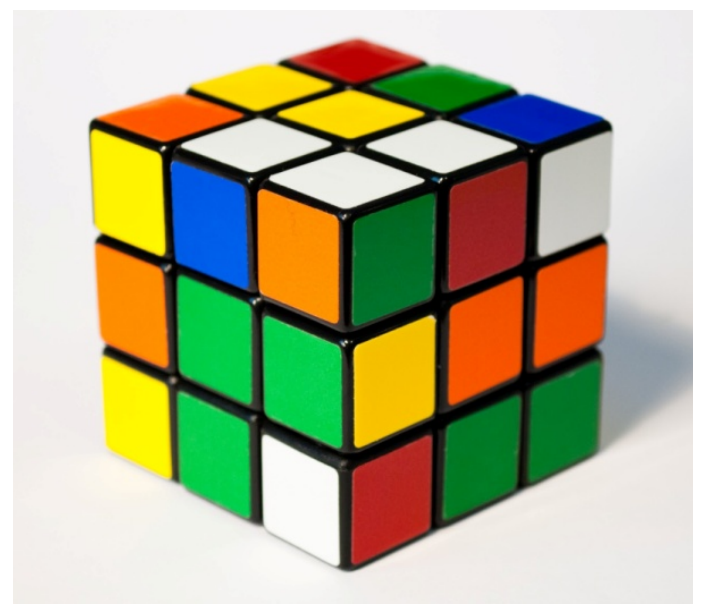

\section{Gambar 8. Rubrik Kube}

Guru dapat menjelaskan bentuk kubus dalam geometri dapat diwakili dengan melihatkan mainan rubrik kube seperti pada gambar 8 tersebut di atas. Seorang guru dapat memberikan contoh lainnya yang berhubungan dengan bentuk kubus lainnya. berikut :

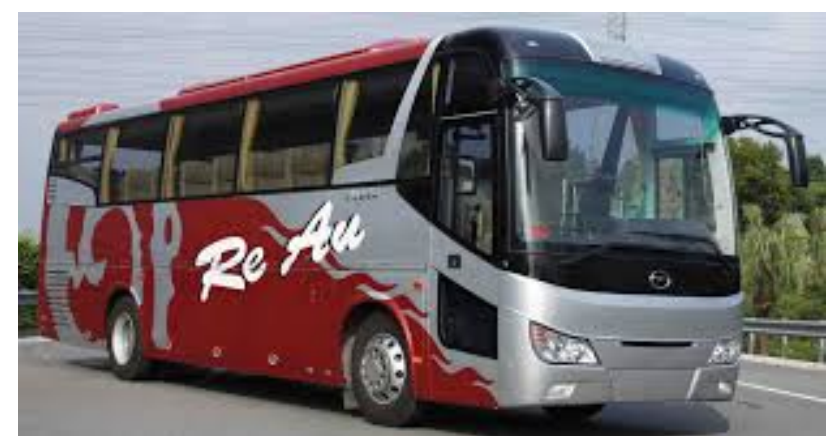

Sumber : http://ealala.blogspot.co.id

\section{Gambar 9. Bus}

Guru dapat meeminta para siswa memberikan beberapa contoh bentuk menyebutkan bentuk geoemtri yang terdapat geometri akan disajikan seperti pada tabel pada mainan mobilan bus seperti pada berikut ini

gambar 9. Untuk lebih jelas dalam 


\begin{tabular}{|c|c|c|}
\hline$\Leftrightarrow$ & $\begin{array}{l}\text { Al Fitrah } \\
\text { Journal Of Early Childhood Islamic Education } \\
\text { ISSN : 2599-2287 } \\
\text { Vol.1 No.2 Januari } 2018\end{array}$ & $\begin{array}{r}\text { Pengajaran Konsep Matematika Pada Anak } \\
\text { Usia Dini } \\
\text { Fatrima Santri Syafri }\end{array}$ \\
\hline
\end{tabular}

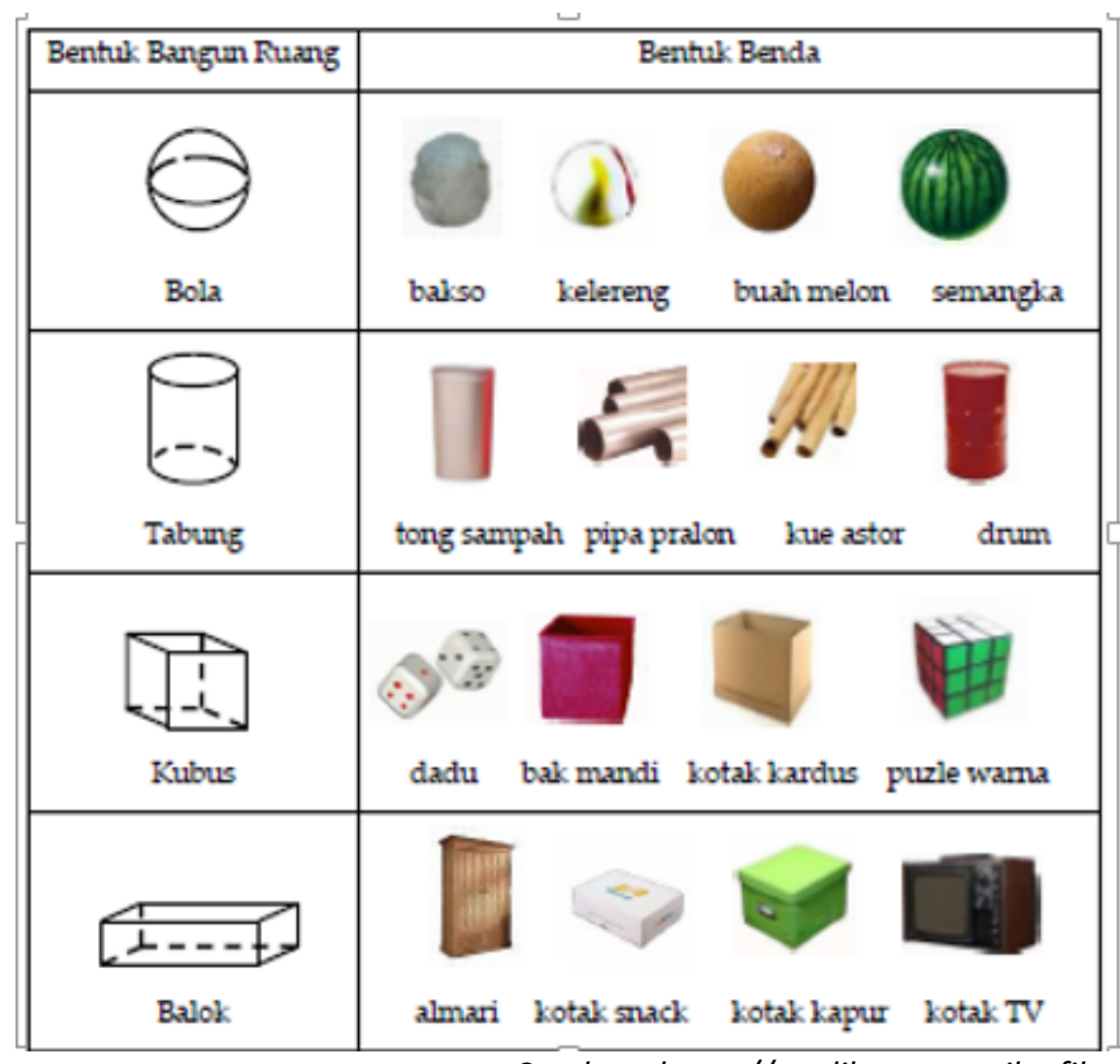

Sumber : https://cerdikmatematika.files.wordpress.com

\section{Gambar 10. Benda-benda bentuk geometri}

Konsep matematika dalam pengajarannya, siswa PAUD dikenalkan dengan beberapa benda yang berada dilingkungan sekitar mereka sehingga konsep matematika tersebut dapat lebih dipahami dan dimengerti oleh para siswa.

\section{Penutup}

Pengalaman matematika tersebut lebih mengenalkan siswa pada konsep matematika. Konsep matematika adalah ide abstrak dalam menggolongkan matematika berdasarkan karakteristik tertentu atau menggolongkan contoh dan bukan contoh dalam matematika. Konsep dasar yang dapat dikenalkan pada siswa PAUD yaitu konsep berhitung dan konsep geometri. Kedua konsep tersebut dalam pengajarannya, siswa PAUD dikenalkan dengan beberapa benda yang berada dilingkungan sekitar mereka sehingga konsep matematika tersebut dapat lebih dipahami dan dimengerti oleh para siswa. Misalnya dalam berhitung, siswa dikenalkan dengan jumlah benda yang ada disekitar mereka, seperti permen, kelereng dan lainnya. Untuk benda geometri misalnya dikenalkan bentuk bola, lingkaran dan lainnya dengan benda-benda yang menyerupai bentuk geometri tersebut. 


\begin{tabular}{|c|c|c|}
\hline & $\begin{array}{l}\text { A1 Fitrah } \\
\text { Journal Of Early Childhood Islamic Education } \\
\text { ISSN : 2599-2287 } \\
\text { Vol.1 No.2 Januari } 2018\end{array}$ & $\begin{array}{r}\text { Pengajaran Konsep Matematika Pada Anak } \\
\text { Usia Dini } \\
\text { Fatrima Santri Syafri }\end{array}$ \\
\hline
\end{tabular}

\section{DAFTAR PUSTAKA}

Arsat. 2007. Meningkatkan Pemahaman Konsep Luas Bangun Datar Melalui Representasi Enaktif, Ikonik dan Simbolik pada Siswa kelas SDN 8 Baruga Kendari. Skripsi. Kendari: FKIP Universitas Haluoleo Kendari.

Brousseau, Theory of Didactical Situations in Mathematics, (Netherlands: Kluwer Academic Publisher, 1997), h.139-142

Clements, D. 2001. Mathematics in the Preschool, (Teaching Children Mathematics: NCTM)

Musliana. 2007. Pengaruh Penggunaan Model Pembelajaran Konstrutivis Terhadap Prestasi Belajar Matematika Siswa Kelas IV SDN 11 Abeli. Skripsi. Kendari: FKIP Universitas Haluoleo.

National Research Council, 2009. Mathematics Learning in Early Childhood: Paths Toward Excellence and Equity (Washington: The National Academies Press)

NCTM.Principles and Standars for School Mathematics. Reston, VA: NCTM. 2000

Novikasari, ifada (2016) Matematika dalam Program Pendidikan Anak Usia Dini (PAUD). Bunayya: Jurnal Pendidikan Anak, Vol 2 (1)

Soedjadji, R. 2000. Kiat Pendidikan Matematika Di Indonesia. Jakarta: Dirjen DIKTI

Solehuddin, Konsep Dasar Pendidikan Prasekolah, ( IKIP Bandung: Tidak Diterbitkan, 1997)
Sperry, S.S., 2006. Early Childhood Mathematics: Third Edition, (Boston: Pearson)

Sujiono, Yuliani Nurani, 2009. Konsep Dasar Pendidikan Anak Usia Dini, Jakarta: PT Indeks. 